\title{
Traditional Accounting vs. Computer Based Accounting: Challenges Faced by Accountants
}

Mohd. Takdir Hossan

Senior Lecturer, Faculty of Business, ASA University Bangladesh, Dhaka, BANGLADESH

*E-mail for correspondence: takdir21@gmail.com

\begin{abstract}
To face much more difficult and challenging the business world in the challenging professional areas, depth knowledge about any particular filed is very much more compulsory. Accounting is essential function for any commerce and industry. All commerce and industries must keep a record of their revenue and expenses.
\end{abstract}

Keywords: Manually Record, E-Accounting, Using Accounting Software like Quick Books, Tally

\section{INTRODUCTION}

The world is changing rapidly. The traditional manual system is going to be improved into technology-based modern system thoroughly. Nowadays, it is not possible in modern world about the accounting without technology. Traditional accounting system refers to the recommended by the father of accounting Luca De Pacioli. The accounting information system is based on what is typically called the accounting cycle and based on the accounting equation.

Computerized based Accounting System refers to the integration of different element systems to produce computerized books of accounts, records and documents. Certainly, Pacioli's original thoughts were nothing short of brilliant regarding proposing a method for recording, maintain, and reporting economic data with a-fairly initial information technology. However, modern world and the profession's desire to move forward allow AIS designers to reconsider the fundamental architecture of the AIS. Moreover, today's technology makes rethinking AIS possible. Although there were stewards, auditors, and bookkeepers in ancient periods, the professional accountant is a 19th-century development.

\section{Objectives of the Study}

- The meaning and details of traditional accounting and Computer-based accounting.

- The scope of Computer-based accounting.

- The differences in recording the entries in traditional accounting and computer-based accounting.

- The challenges of an Accountant.

\section{Methodology}

Data has been collected from secondary sources only because there is no scope to use the information from a primary source. Or on the other hand, the primary sources are not available. To get information from the secondary sources for collecting data and visited some libraries to collect some sorts of books related to the topic. I have also visited computer lab to collect the information from the internet. I have read the books, magazines, newspapers, journals and the articles from internet. However, the data used in the study has been further analyzed and processed for the study.

\section{LITERATURE REVIEW}

\section{Traditional Accounting}

Traditional accounting refers to the accounting transactions according to the method suggested by the father of accounting Luca De Pacioli. Luca Pacioli was a Franciscan monk. He lived in Italy during the 1500s. He is often called the father of double-entry bookkeeping. Pacioli was not the inventor, but he was "the first accountant to combine his knowledge with Johan Gutenberg's technology to instruct the world on the subject in print (Crosby, 1997)."

The traditional accounting information based on what is naturally called the accounting cycle and is based on the basic accounting equation. Although the concepts documented by Pacioli have been adapting over the years, the essence of his original proposal remains constant. 
The accounting cycle is a series of sequential steps leading to the creation of the financial statements and each reporting period. The first there steps in the accounting cycle require the prime amount of time, and occur continuously throughout the period. The frequency of step 3 , posting, depends on the volume and nature of the recorded transactions. For example, firms with many daily cash transactions often post to the cash account daily. Steps 4 through 9 occur only at the fiscal year-end. And 10, reversing entries, is optional and occurs at the beginning of the next accounting period (Hollander et al. 2000).

\section{Weaknesses of Traditional Accounting System}

There are so many weaknesses in the traditional accounting system. The professionals, who want to provide business solutions, are not capable of providing efficient and effective business solutions by traditional accounting. Sometimes a total of 24 entries are used to record two simple events! These transactions do not take into account any discounts, currency exchange rates, billing adjustments, or the possibility of value-added taxes for crossing international boundaries. So it is very hard to quickly get out of hand in promulgating hundreds of different ledger and subsidiary ledger systems to accommodate the variety of information and processing requirements across an organization (D. P. Andros, 1992).

There are so many groups in the company and outside who wants to use the accounting information such as production people, marketing people, personnel people, executive people, investors, suppliers, and creditors. They want different types of information of the same transactions. Traditionally, system designers have addressed the diversity of information customer needs by building a different system for each desired view. Each system captures slightly different data about the same business event, with each system using its own classification scheme to select and record a subset of available data about the event. It is time-consuming and difficult to keep the records (Thomas Walther, 1997).

\section{Computer Based Accounting}

Computerized based Accounting System refers to the integration of different component systems to produce computerized books of accounts and computer-generated accounting records and documents. Undoubtedly Pacioli's original thoughts were nothing tiny of brilliant in terms of proposing a method for recording, maintain, and reporting economic data with a fairly primitive information technology. However, today's world and the profession's desire to move forward allow AIS designers to rethink the basic architecture of the AIS. Moreover, today's technology makes rethinking AIS possible (McCarthy, 1998).

\section{SCOPE OF COMPUTER BASEd ACCOUNTING SYSTEMS}

There are some areas where the computer-based accounting is used broadly. Obviously, there are some merits to use the computer-based accounting systems rather than traditional accounting system. In this chapter, the scope of computer based accounting will be shown by differentiating between the process of traditional accounting and computer based accounting.

\section{Traditional Sales and Collection Process}

In a manual sales or collection process, a paper is using as the primary means to capture and store business data and communicate information to customers. Paper records also serve as the audit trial tor documenting the process. Data about the sales or collection process are captured and maintained by various business functions that participate in the process. As a result, process data are scattered across various departments (e.g. the Sales Order Department, the Shipping Department, the Billing Department, and the Warehousing Department). Because no unit has a complete picture of the sales or collection data, various departments store duplicate data. Paper is also used to communicate authorizations between departments and to external parties (Cherrington, 2000).

The sample data flows commonly associated with the sales or collection process is given below.

Customer order: A data flow originated by and sent from the customer. It typically includes data about the customer, where to ship the goods, order terms and conditions, the items the customer wants to order, and payment terms. The customer order is used to create the sales order.

Sales order: A data flow created internally to document order and the approval the tan order. It often includes the same data items as the customer order. Copies of the sales order are used to be communicating authorization to initiate other activities in the process.

Picking slips: A data flow that is sent to the warehouse to authorize the movement of ordered goods from warehousing to shipping. It is often a copy of the sales order.

Packing slips: A data flow that is sent with the goods shipped to a customer. Often, the data flow is labeled with a "This is not a bill" message.

Shipping notice: A data flow that describes the packages shipped the carrier, the route, and customer information.

Sales invoice: A data flow listing the merchandise, with prices, that have been delivered or sent to a buyer. It is a statement of money owned for goods or services supplied.

Remittance advice: A data flow accompanying customer payment.

Deposit slip: A data flow listing the monies actually transferred from an organization to a financial institution.

Customer check: A data flow that authorizes the transfer of funds from the customer to the seller.

Open sales order: An open sales order considered when the order has not been physically delivered. They remain open until they are shipped and billed. 
Open sales invoice: An open sales invoice is consider detailed documents. They remain open until customers are paid.

\section{Automated Sales and Collection Process}

Typical information technology applications automated the business and information process rules of the manual system. An automated system is very similar to a traditional manual system; document flow is similar, as is a large amount of duplicate data. However, since authorizations and data access can be providing through computer screens there is a potential decrease in the amount of paper (Hollander et al. 2000).

Each computer-processing symbol denotes computer programs that include a list of instructions for the computer. Each program can include screens for collecting data; edit checks on the data entered, instructions for processing and storing the data, security procedures (e. g. limiting access via passwords or user IDs), and steps for generating and displaying output. To understand the files and their use, it is essential to consider their contents (their record layouts). The input documents and the files must contain the data necessary to generate the desired output.

The content of the computer-readable files used in an automated system is similar to the paper files used in the manual. Data collection and storage be still define by the chart of accounts that govern this process: Sales, Sales Returns and Allowances, sales Discounts, Cost of Goods Sold, Bad Debt Expenses, Marketing Expenses, Cash, Accounts Receivable, Allowance for Doubtful Accounts, and Inventory. The automated sales or collection process can use batch processing (by accumulating a group of customer orders before processing) or online processing (by processing order information as it occurs) (Joseph W. Wildnson, 1997).

\section{Traditional Acquisition and Payment Process}

The acquisition or payment process includes the business events associated with buying, maintaining, and paying for goods and services needed by the organization. These processes are acquiring raw materials, parts, and other resources contained in finished products or services. It also includes the acquiring, and paying for a variety goods and services (e. g. utilities, supplies, insurance, repairs, maintenance, research, development, and professional and legal services) (Michael Hammer, 1990).

The flows and reports commonly associated with the acquisition or payment process:

Purchase requisition: An internal data flow requesting the purchase of specific goods or services. Various people throughout the organization use this data flow to request particular items.

Purchase order: A data flow sent to a vendor as a formal request for the vendor to sell and deliver specified products or services at a designated price.
Receiving report: A data flow used to summarize the receipt of raw materials or merchandise from vendors. The receiving department usually prepares the receiving report upon acceptance of each shipment of goods.

Packing slip: A data flow that be sent with the goods shipped to a customer. The vendor or supplier creates the packing slip.

Bill of lading: A written receipts given by a carrier for goods accepted for transportation. The carrier that delivers or transport cargo will usually provide a bill of lading to the company shipping the items (vendor).

Vendor's invoice: The vendor sends the invoice to the buyer as a request for payment for merchandise delivered or services provided.

Check: A data flow used to draw money from a bank account and transfer it to another entity. Treasury Department is frequently used to pay for items purchased by a company.

Material requirement planning: The Software program that identifies the raw materials essential, and the timing of the requirement, to produce a particular number of units of finished goods. This planning is used to determine the number of raw materials needed to meet production levels projected for the next period.

Open purchase request: Purchase request that has not been yet officially unused or upgraded to purchase order status.

Open purchase order: Purchase order that has been sent to a vendor, but the items ordered has not been yet received and a liability has not been recognized. A copy of the purchase order which has been issued to a vendor and frequently maintained by Accounts Payable in an open purchase order file until the goods or services have been received.

Open invoice: The purchases related bills that have been approved for payment, but cash has not yet been disbursed to pay the liability.

Stock status report: A report on each inventory sold by a company, including information about items out of stock, below a minimum stock level, and turnover analysis.

Vendor performance report: These reports are summarizing each vendor's performance for a given time. Items on the report may include time between order and delivery, the frequency of back-ordered items, a quantity of merchandise received, and volume of purchases.

\section{Automated Acquisition and Payment Process}

Some organizations are beginning to use information technology to acquisition and payment process and develop the efficiency of the purchaser or supplier affiliation. Many companies require or encourage the use of electronic data interchange (EDI), a form of electronic commerce. EDI is the transmission of business data flows 
between or within organizations in a structured, machineretrievable format. Electronic data interchange transmission differs from a fax or unformatted electronic mail. EDI is typically batch related, rather than interactive, and predominantly used for business-to-business, rather than business-to-consumer, communications (D. P. Andros, 1992).

EDI communication often requires specialized hardware and software. The electronic data flow is called a transmission set, and the format adheres to some specified standard such as ANSI X12 (American National Standards Institute) or EDIFACT (Electronic Data Exchange for Administration Commerce and Transport). A communication interface gives a computer the ability to transmit and receive transaction sets. This EDI interface moves data to and from the appropriate application software. The application software then uses the EDI transaction set data as the input for internal processing (Michael Hammer, 1990).

\section{Traditional Manual Payroll Process}

The non-sophisticated manual payroll process uses an extensive amount of paper to capture, convey, store, and report information. The process begins in the personnel function when an employee is hired. The personnel division appointed the employee, authorizes a rate of pay, and collects information about marital status and number of dependents for payroll deduction purposes. As employees arrive and leave work they record their hours on time cards with Timekeeping to show the time they entry and exit. As they work during the day, employees record on job time ticket the amount of time they spend working on individual jobs. The job time tickets are reviewed by the production supervisors and transferred to Timekeeping to be reconciled with the time cards. If employees properly punch in and out, accurately record time worked on job tickets, and has no wasted time between jobs, the total time on the job time tickets should equal the time recorded on the time cards (Thomas Walther, 1997).

This process has several primary data flows and control points. Key data flows include the job time tickets, time cards, payroll register, voucher, and checks to the payroll account and individual employees. There are also several significant control points. Controls include a review of the job time tickets by the factory supervisor and Timekeeping's reconciliation of the job time tickets and the time cards. Such adjustments and reviews can identify errors or discrepancies. For example, if an employee can bypass the timekeeping control and punch in for a friend, it is difficult to post time to jobs for the friend during the day without a supervisor discovering it. Finally, the separation of duties between the various departments is also important in a manual system. By only paying employees who have been hired by personnel and who have worked time that has been approved by a supervisor, people are prevented from entering fictitious employees on the records and paying them for the time they did not work. Authorization duties (performed by personnel) are separated from record-keeping duties (performed by Timekeeping, Payroll, Accounts Payable, and Cost Accounting) and custodial activities (Henry Johansson, 1997).

\section{Computerized Payroll Process}

A time ticket, or similar recording process, continues to serve as input to the payroll process. Time and attendance are determined by calculating the time between when employees enter work and when they leave work (as well as the department they work in for a process costing system or the jobs they worked on for a job order costing system). A payroll clerk prepares some batch total early in the process, preferably as soon as the time tickets are first accumulated. The batch total could be the number of employees who worked (a record count), the total hours worked (a "financial" total), or the total of the employees' identification numbers (a hash total). The batch total is used to verify the accuracy of the payroll process. For example, if a record count were used for the control total, we would expect the number of checks printed by the computer to equal the record count. If total hours worked were used, we would expect the total of the hours paid on the summary report generated by the computer to equal total hours worked (John Dunleavy, 1997).

A control group executes one added control in a computerized system. This group of people has the responsibility to review the activities of the Data Processing Department. For the payroll process, the control group receives the batch totals and the two exception and summary reports. They compare the batch totals with information on the exception and summary reports to verify that data have not been added or lost during processing. They follow up on errors and exceptions to identify their cause and see the appropriate corrections are made. For example, if an employee has time card data, but is not listed as a valid employee in the masters file, the control group will want to know why. Also, if an employee has 90 hours of work in a week, the control group will want to see if it is legitimate, why someone is working so many hours, or how 90 hours was recorded when the person worked few hours (Elizabeth Hjelm, 1997).

\section{The Challenges Faced by Accountants}

\section{The Changing Patterns of Accounting}

The information technology will affect the accounting profession since the early days of modern information technology. Bob Elliot, a national partner with the accounting firm of KPMG or Peat Marwick, is one of the more outspoken accounting futurists. In his 1992 "Accounting Horizons" article, Elliot begins with "Information Technology (IT) is changing everything." Drawing on the work of Alvin Toffler, Elliot uses the 
imagery of the "third wave" to predict impending and significant changes in accounting practice, education, and research. Elliot concludes his article with the following:

"IT is creating a wave of change that is crashing over accounting's shoreline. It crashed across the industry in the 1970s. Then it crashed across the services in the 1980s. And it will crash across accounting in the 1990s. It is changing the way business is done and the problems faced by managers. Managers now need new types of information in order to make decisions, so internal and external accounting must be changed. Higher education can simply react to these changes, or it can take a more active role, embracing the future, adapting rapidly, and facilitating the adaptations of others. The challenges to academic accountants are to invent the third wave accounting paradigm and produce the graduates who can function effectively in the third-wave organizations they will be joining. The challenges to non-academic accountants are to make the organizational and political changes to implement the new accounting paradigm (B. Elliott, 1992)."

\section{The Challenges of Accountants}

The world is changing very rapidly. The traditional accounting is being computer-based accounting in all the perspectives. In very near future there will not be any perspective of traditional accounting which will not be brought into computer based accounting systems. So there are so many challenges waiting for the accountants. In light of the financial crisis that hit the world scene beginning in 2008, financial authorities have placed a greater emphasis on accountability and transparency in all financial sectors. As the International Auditing and Assurance Standards Board notes, the accounting industry has been affected by this need for greater transparency also. As financial regulators move forward, and as the world economic scene continues to change, accountants will face several different challenges (Jared Lewis, 2011).

\section{The Demand for Accountant is decreasing}

In the past, the accounting information was recorded by manually. So, it was necessary to keep number of skilled accountants in the company to keep the accounting records correctly and efficiently. But, now the technology has changed this situation. A company can keep the huge number of accounting information easily by using the technology. So, now it is not necessary to maintain large number of accountants in the company. That's why; the demand of the accountant has been decreased. In the future, it may be further decreased (Hollander et al. 2000).

\section{Dependency on the Accountant is decreasing}

In the long-ago, if a company wanted to decide about any matter related to the accounting information, the company would depend on the accountant to know the updated accounting information. But, at the present time, it is not necessary for the company to depend on the accountants.
The computer-based accounting systems can provide any updated accounting information within a few seconds. So, if the dependency on the accountant is decreased rapidly, the accountant profession in the future will face the challenges (Hollander et al. 2000).

\section{Auditor's activities are decreasing}

Periodically auditing was very much necessary for the company in the past. The period may be quarterly, half yearly, or yearly. When a company needed to know about the accuracy of the accounting data or transaction, it was necessary to go to the accountant to prove the accuracy of the records. But, it is not necessary now. The computerbased accounting system is built up in such a way that, it will update all the accounting information within very short time, even it can be daily. So, in the past, the accountant was necessary to audit more times. But, now it is not necessary to audit so many times in years. Even only one audit per year is enough for the company. So, it is a big challenge for the accountant. And these challenges are creating only for the developing of the computer-based accounting system (Hollander et al. 2000).

\section{Use of Technology}

While business technology can provide numerous benefits to a company, management accountants can struggle using internal applications for accounting purposes. The inability to develop reports accurately and prompt using technology can result in accountants having to prepare manual reports, delaying their job functions. So, it is a challenge for the accountant to know the application of the accounting software.

\section{Fair Value Accounting}

The International Auditing and Assurance Standards Board note the need for accountants to be able to perform audits by fair value for financial investment vehicles. In the aftermath of the financial problems that began to emerge in 2008 and 2009, accountants must be aware of the potential for accountants to either misinterpret financial data or be misled because of the inability to obtain accurate market information. Accountants must have extensive knowledge of market valuation techniques to ensure that they are assigning the proper value to investments (Thomas Walther, 1997).

\section{FINDINGS}

After analyzing the literature review, some findings have been observed. The findings are:

The world is changing rapidly: Technological development is improving rapidly. All the manual systems are going to be converted into computerized systems. In very near future, it may be noticed; there will be no manual system of operation. So, it is high time to cope with the technological development. 
The Traditional accounting system is going to be eliminated: In the present time, there are some scopes of traditional accounting. But, in very near future, it is observed and estimated that, the scope of traditional accounting systems may be gone forever. The computer-based accounting system will be only the system to keep the record of accounting transactions.

Three main reasons of dependency on computer based accounting system: The computer-based accounting system is being used for three reasons. The main reason is to eliminate the human errors. When the accounting records are kept manually, there is a greater chance of errors. Secondly, it is not possible to be more efficient is the work is done manually than if it is done by computer. Finally, the use of paper will be reduced by using a computer. That will reduce the costs and time.

There are some scopes of traditional accounting still now: Although the technology is developing rapidly, there are some scopes of traditional accounting systems right now. The main reason is the cost of traditional accounting system in some cases is lower than the computer-based accounting system in those areas. In the future the scenario may be changed, but, right now it is going on with the traditional accounting system efficiently and effectively.

The Scope of the Accounting Jobs is decreasing: For the technological involvement in the accounting sectors, accounting software is enough for keeping the large number of accounting records. The scope of the accounting jobs is decreasing day by day. The more people are going to be jobless.

Organizations can make an immediate decision: If organizations want to make any decision by considering the accounting information, it is not necessary to wait for a long time to get the accounting information. It is only a matter of one click to get the relevant accounting information to make the decision. The dependency on the accountants has been reduced dramatically.

Costs, time and labor have been saved: The cost of paper has been saved by using a computer to keep the record of accounting transactions. So many transactions can be recorded and transferred within very short time. The employee in the organization has been reduced. So again the extra cost of having extra employees has been reduced in the organization by using computerbased accounting system.

The Scope of auditing has been decreased: The computerbased accounting system is built up in such a way that, it will update all the accounting information within very few time, even it can be daily. So, in the past, the accountant was necessary to audit more times. But, now it is not necessary to audit so many times in years.
Even only one audit per year is enough for the company.

The professional judgment is still necessary: Although the technology has covered the areas of recording and transferring the accounting transactions, the professional judgment is still essential to make the effective decisions. For example, computer based accounting system may be able to record the depreciation. Sometimes it is able to transfer the depreciation by making proper entry. But computer system is not able to make any professional judgment about what should be the expected economic life of the assets and what should be the appropriate method to calculate the depreciation. It depends on an accountant.

\section{RECOMMENDATIONS}

- The accountants should be able to cope with the changing world. The accountants should be able to be expert in the use of technology.

- Traditional accounting is going to be eliminated. So, the main task for the accountants is to keep the accounting secure in the changing world by keeping touch with the technology.

- The non-accounting background people are getting the accounting jobs. They can work with the technology, but they are not able to make any professional judgment, that's why accounting is facing some problem. So, the organizations should recruit the accounting background people for the accounting jobs.

- The scope of the accounting jobs is going to be decreased. So, it is the duty of the accountants to be able to skilled in the use of technology to get the scared accounting job.

- The technological development should be in such a way that will lead the world to keep the accounting record and transferring at low cost. If it is possible the development of accounting areas will get the new dimension.

- At last, it is now the duty for the accountants to secure the accounting in the very near future. The accountants should maintain good ethics. The technology can give everything but not ethics. It is the main challenge for the accountants to maintain the ethics in the accounting profession to make this profession reliable to the public.

\section{CONCLUSION}

While the only change is constant and everything other than change is changing in the world. So, it is clear that, accounting system must be changed and it is changing actually. The traditional accounting system is being converted into computer-based accounting system. The traditional sales and collection process has been changed to automated sales and collection process. The traditional 
acquisition and payment process has been changed to automated acquisition and payment process. The traditional payroll process has been changed to the automated payroll process. Everything is changing from manual process to automated computerized process.

The computer-based accounting system is being popular. Although, there are so many areas of accounting where computer based accounting is not cost effective till now. Those areas are maintaining the traditional accounting system. The research is going on to apply the computer based accounting system in those areas. We can expect that, in very near future, those areas will be brought into the scope of computer based areas.

Accountants are facing some challenges because of development of computer-based accounting system. The accounting jobs are being unavailable for the people because, it is not necessary to recruit so many employees to keep the accounting records for the organizations. Technology can keep the accounting records correctly and efficiently. But is does not imply that, accountant is nothing in the present world. There is the scope of professional judgment in the accounting related areas. Although the technology has covered the areas of recording and transferring the accounting transactions, the professional judgment is still necessary to make the effective decisions.

\section{BIBLIOGRAPHY}

A. CROSBY (1997) The Measure of Reality: Quantification and Western Society $\left(2^{\text {nd }}\right.$ Ed.), Cambridge University Press, Melbourne, Australia.

A. PIPKIN (1989) “The $21^{\text {st }}$ Century Controller," Management Accounting, p. 24

A. TOFFLER (1990) The Third Wave ( $5^{\text {th }}$ Ed.), Bantam Books, New York, U.S. A.

B. ELLIOTT (1992) The Third Wave Breaks on the Shores of Accounting (2 $\left.{ }^{\text {nd }} E d.\right)$, Accounting Horizons, New Jersey, U.S.A.

B. P. SHAPIRO, V. K. RANGAN and J. J. SVIOKLA (1992) “Staple Yourself to an Order," Harvard Business Review, JulyAugust, pp. 113-122.

D. P. ANDROS, J. O. CHERRINGTON, and E. L. DENNA (1992) Reengineer Your Accounting System the IBM Way ( $4^{\text {th }} \mathrm{Ed}$.), Financial Executive, U.S.A.

DRUCKER, (1997) "The Future That Has Already Happened," Harvard Business Review, September- October, pp. 20-24.

ENOTES (2011) 'Accounting Information systems,' [online] (cited 24 July 2011) Available from http:/ / www.enotes.com/business-financeencyclopedia/accounting-information-systems.html

G. A. MILLER (1956) “The Magical Number Seven, Plus or Minus Two: Some Limits on Our Capability for Processing Information," The Psychological Review 63, no. 2, March, pp. 81-97.

G. SAMUELS (1994) “CD-ROM's First Big Victim,” Forbes, February 28, pp. 42-44. HOLLANDER, DENNA and CHERRIGTON (2000) Accounting, Information, Technology, and Business Solutions ( $\left({ }^{\text {nd }}\right.$ Ed.), Irwin McGraw Hill, New York, U.S.A.
GEOFFREY SMITH (1992) “The New Realism in Office Systems: Computers Can't Take the Place of Good Management-But They Can Help," Business Week, June 15, pp. 128-133.

H. T. JOHNSON and R. S. KAPLAN (1987) Relevance Lost: The Rise and Fall of Management Accounting ( $8^{\text {th }}$ Ed.), Harvard Business School Press, London, U. K.

J. CARLTON (1996) "Think Big: The Net Gives Small Business a Reach They Once Only Dreamed of," The Wall Street, June 17, pp. R27.

JARED LEWIS (2011) 'Challenges of Accountant,' [online] (cited 24 July 2011) Available from http:/ / smallbusiness.chron.com/challenges-ofaccountants.html

L. T. PERRY and E. L. DENNA (1995) "Reengineering Redux," Business Process Re-engineering \& Major Organizational Change, February.

LINDA ACKERMAN (1986) "Development, Transition or Transformation: The Question of Change in Organizations," OD Practitioner, December, pp. 1-8.

M. PORTER (1985) Competitive Advantage: Creating and Sustaining Superior Performance $\left(12^{\text {th }}\right.$ Ed.), the Free Press, New York, U.S.A.

MARSHALL B. ROMNEY, and PAUL JOHN STEINBART (2003) Accounting Information Systems (9th Ed.), Pearson Education (Singapore) Pte. Ltd., F.I.E. Patparganj, Delhi, India.

MICHEAL HAMMER (1990) "Business Process Reengineering: Don't Automate, Obliterate," Harvard Business Review, July-August, pp. 104-112.

N. GROSS, P. C. JUDGE, O. PORT, and H. WILDSTROM (1998) "Let's Talk: Speech Technology Is the Next Big Thing in Computing," Business Week, February 23, pp. 60-72.

NEAL TEMPLIN (1998) "Big Cars and Little Spaces Cause Mayhem," The Wall Street Journal, March 11, pp. B1, 8.

PENERBIT (2009) 'Computer-Based Accounting Systems,' [online] (cited 01 August 2011) Available from http:/ / www.penerbit.utm.my/onlinejournal/39/E/JTKK39E2.pdf

R. ECCLES (1991) "The Performance Measurement Manifesto," Harvard Business Review, January-February, p. 131.

R. KAPLAN and D. NORTON, (1992) "The Balanced ScorecardMeasures That Drive Performance," Harvard Business Review, January-February, pp. 71-79.

RECHARD GREEN and KATHERINE BARRETT (1994) "Auditing the Accounting Firms: Under Heavy Fire, the Big Six Firms Are Finally Changing How They Do Business," Financial World, September 27, pp. 30-34.

SMALL BUSINESS (2010) 'Differences Between Traditional Accounting and Computer-Based Accounting,' [online] (cited 28 July 2011) Available from http:/ / smallbusiness.chron.com/difference-betweentraditional-accounting-computerized-accounting-4021.html

THOMAS WALTHER, HENRY JOHANSON, JOHN DUNLEABY, and ELIZABETH HJELM (1997) Reinventing the CFO: Moving from Financial Management to Strategic Management ( $2^{\text {nd }}$ Ed.), McGraw-Hill, New York, U.S.A.

WHITE STAG (2011) 'Getting and Giving Information', [online] (cited 28 July 2011) Available from http://www.whitestag.org/skills/getting_giving_information.html

$--0-$ 
How to Cite: Hossan, M. (2018). Traditional Accounting vs. Computer Based Accounting: Challenges Faced by Accountants. American Journal of Trade and Policy, 5(2), 73-80.

\section{SOCIAL SCIENCE RESEARCH NETWORK}

2171 Monroe Avenue, Suite 203, Rochester, NY 14618, USA http://www.ssrn.com/en/

SSRN Link: http://www.ssrn.com/link/American-Journal-Trade-Policy.html 